\title{
Skew decks in reinforced concrete bridges
}

\section{Lajes esconsas em pontes de concreto armado}
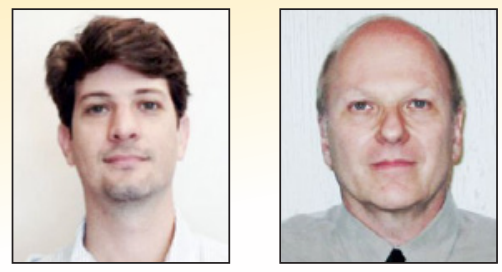

B. F. ROCHA a

bernardorocha@id.uff.br

M. SCHULZ a mschulz@id.uff.br

\begin{abstract}
This research investigates reinforced concrete plates and shells with skew reinforcement whose directions are not aligned with the principal internal forces. Two normal forces, one tangential force, two bending moments, and one twisting moment are defined in the plane of the element. The analysis includes two shear forces in the transverse direction. The membrane and flexural forces are distributed between two panels at the upper and lower faces of the element. The smeared cracking model, equilibrium considerations, and plasticity approach yield the design equations of the skew reinforcement. The slab reinforcement of flat bridges, with and without lateral beams and girder bridges are compared considering different skew angles. The minimum reinforcement criteria of skew meshes are discussed. The results show that skew reinforcement yields higher steel and concrete stresses.
\end{abstract}

Keywords: shell structures, shell design, skew reinforcement, slabs, skew bridges.

\section{Resumo}

Essa pesquisa investiga estruturas laminares de concreto armado com armaduras esconsas e oblíquas em relação às solicitações. Duas forças normais, uma força tangencial, dois momentos fletores e um momento volvente são definidos no plano do elemento. A análise inclui duas forças cortantes na direção transversal. As solicitações de membrana e flexão são distribuídas entre duas chapas nas faces superior e inferior do elemento. As armaduras esconsas são calculadas através das condições de equilíbrio e de uma abordagem plástica pelo modelo da chapa fissurada. O trabalho compara as armaduras das lajes de pontes em laje, pontes em laje com vigas laterais e pontes em vigas múltiplas segundo diversos ângulos de esconsidade. Os resultados mostram que a utilização de malhas esconsas aumenta as tensões no aço e no concreto. Critérios para armaduras mínimas em malhas esconsas são discutidos.

Palavras-chave: estruturas laminares, dimensionamento de cascas, armadura esconsa, armadura oblíqua, pontes esconsas.

Departamento de Engenharia Civil da Universidade Federal Fluminense, Niterói, RJ, Brasil. 


\section{Introduction}

In -plane loads subject reinforced concrete shell elements to biaxial stresses and transverse loads subject them to triaxial stresses. Therefore, shell reinforcement, whose directions are not necessarily aligned with the principal stress resultants, must consider the inplane internal forces $F_{x}, F_{y}, F_{x y}, M_{x}, M_{y}$, and $M_{x y}$, and the transverse shear forces $F_{x z}$ and $F_{y z}$ (Figure 1).

The classical smeared cracking model is widely used in reinforced concrete analysis. Falconer [1] defined the equilibrium equations of a plane element by considering a compression field of concrete stresses. Based on the plasticity approach, Nielsen [2] established the design equations for the orthogonal reinforcement of a concrete panel subjected to membrane forces. Wood, Mills, and Armer [3] [4] discussed the reinforcement design of slabs whose principal bending moments were not aligned with the orthogonal reinforcement. Baumann [5] established the equilibrium equations for a reinforced concrete shell element subjected to membrane forces, flexural moments, and torsional moments by distributing the internal forces between two panel elements on the upper and lower faces of the shell. The reinforcement design of both panels subjected to only membrane forces was established by considering linear elastic behavior and minimizing the strain energy. The CEB-FIP [6] adopted the same internal force distribution but the reinforcement design was based on the yield conditions established by Nielsen [2]. The compression field theory, proposed by Mitchel and Collins [7], introduced the general equation that estimates the angle of the compression struts. Schulz [8] presented a rational theory for reinforced concrete shell elements subjected to flexural moments, torsional moments and in-plane forces. Vecchio and Collins [9] introduced the modified compression field theory considering the tension stresses across the cracks, tension stiffening, and compression softening. Polak and Vecchio [10] used the same model for the experimental and theoretical analysis of reinforced concrete shells. Schulz [11] applied the smeared cracked panel theory to thin-walled reinforced concrete beams by considering the normal and shear forces, bending moments, Saint-Venant torsion, warping torsion, and bimoment. Schulz and Santisi D'Avila [12] investigated reinforced concrete shells with in-plane and transverse forces by dividing the shell element into three-dimensional layers with triaxial behavior. The reinforcement design of shell elements with skew reinforcement presented by Schulz and Oliveira [13] is an extension of the method proposed in CEB-FIP [6]

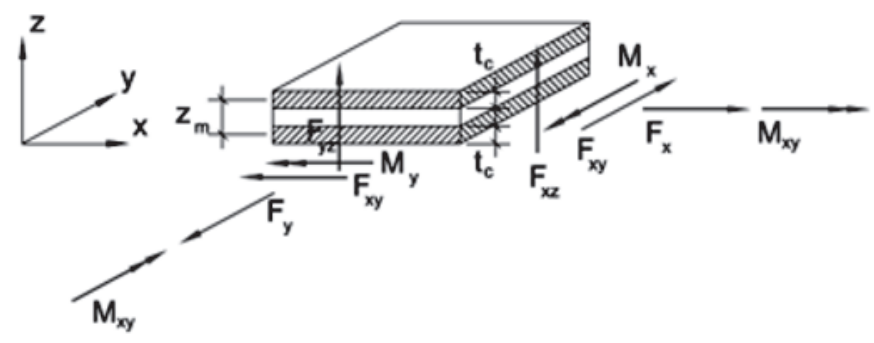

Figure 1

Shell element internal forces
This paper discusses the mechanical behavior of reinforced concrete shell elements and the skew reinforcement design for concrete bridge decks by considering in-plane internal forces and transverse shear forces. The slab reinforcement of flat bridges with and without lateral beams and the slab reinforcement of girder bridges are compared considering skew angles between $0^{\circ}$ and $45^{\circ}$. The formulation simplifies manual calculations and computational implementation. Design recommendations and minimum reinforcement criteria are proposed. The results show that skew reinforcement yields higher steel and concrete stresses.

\section{Mechanical model}

\subsection{Simplifying hypotheses}

The mechanical model is based on the following simplifying hypotheses: concrete tension forces are neglected; concrete cracks have infinitesimal thickness and are uniformly distributed; the compression stresses are in the same direction as the concrete struts between the cracks.

It is also considered that the crack directions are not affected by the loading history. The secondary effects, such as aggregate interlock and dowel action, are neglected. The mechanical model does not include compression reinforcement that reduces concrete compression stresses.

The concrete strength is affected by a constant reduction factor $\mathrm{k}=$ 0.60 , as recommended by Eurocode 2 [14]. This factor includes the Rüsch effect $(0.85)$ and concrete strength softening $(0.70)$ caused by tensile strains in the directions transverse to the compression, as discussed by Robinson and Demorieux [15].

\subsection{Distribution of internal forces between two panel elements}

Panels and membranes are defined as two-dimensional structures subjected to only in-plane normal and shear forces. Plates and shells include bending moments, torsional moments and transverse shear forces. The edges of the two-dimensional elements have unit length (Figure 1). The in-plane internal forces $F_{x^{\prime}}, F_{y^{\prime}}, F_{x y^{\prime}}$ $M_{x}, M_{y}$, and $M_{x y}$ and the transverse forces $F_{x z}$ and $F_{y z}$ represent design values that include the corresponding load factors.

Two panels are defined on the upper and lower faces of the shell with constant thickness $t$ (Figure 1). The bending and torsional moments are removed from the problem by distributing the internal forces between both panels. The membrane forces per unit length (Figure 2) are given by:

$f_{x}=\frac{F_{x}}{2} \pm \frac{M_{x}}{z_{m}}$

$\mathrm{f}_{\mathrm{y}}=\frac{\mathrm{F}_{\mathrm{y}}}{2} \pm \frac{\mathrm{M}_{\mathrm{y}}}{\mathrm{z}_{\mathrm{m}}}$

$\mathrm{f}_{\mathrm{xy}}=\frac{\mathrm{F}_{\mathrm{xy}}}{2} \pm \frac{\mathrm{M}_{\mathrm{xy}}}{\mathrm{z}_{\mathrm{m}}}$

where $z_{m}$ is the lever arm. The tensile forces are positive. 


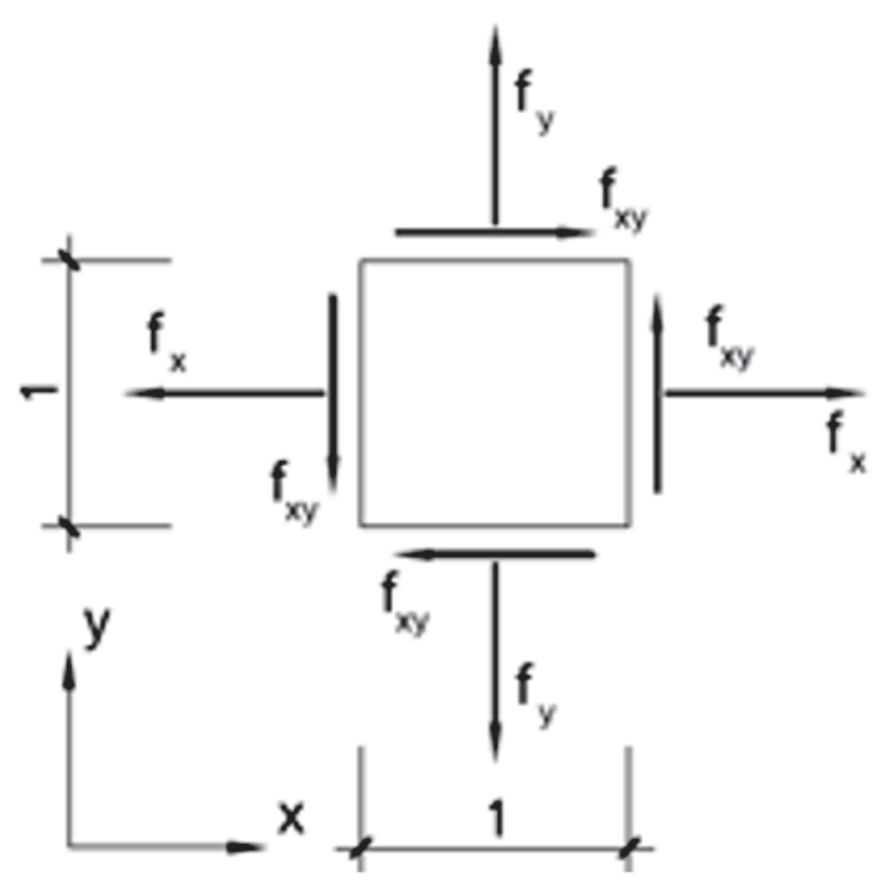

Figure 2

Panel internal forces per unit length

The panel thickness $t_{c}$ and the lever arm $z_{m}$ are approximately defined as:

$\mathrm{t}_{\mathrm{c}}=\mathrm{k}_{\mathrm{c}}\left(\frac{\mathrm{d}_{\mathrm{x}}+\mathrm{d}_{\mathrm{y}}}{2}\right)$

(4)

$\mathrm{z}_{\mathrm{m}}=\mathrm{k}_{\mathrm{z}}\left(\frac{\mathrm{d}_{\mathrm{x}}+\mathrm{d}_{\mathrm{y}}}{2}\right)$

where $d_{x}$ and $d_{y}$ are the effective depth in the $x$ and $y$ directions, respectively. Leonhardt [16] recommends $\mathrm{k}_{\mathrm{c}}=0.3$ and $\mathrm{k}_{\mathrm{z}}=0.9$. The panel thickness $t_{c}$ can be increased on predominantly compressed elements if the lever $\mathrm{arm} \mathrm{z}_{\mathrm{m}}$ is correspondingly reduced (Eurocode 2 [17]).

Bertagnoli, Giordano and Mancini [18] proposed a genetic algorithm by varying the thickness of the upper and lower plates and lever arms. Schulz [11] divided the shell element into membrane layers whose stresses and strains satisfied equilibrium and compatibility equations.

The principal forces per unit length are:

$\mathrm{f}_{\mathrm{I}}=\frac{\mathrm{f}_{\mathrm{x}}+\mathrm{f}_{\mathrm{y}}}{2}+\sqrt{\left(\frac{\mathrm{f}_{\mathrm{x}}-\mathrm{f}_{\mathrm{y}}}{2}\right)^{2}+\mathrm{f}_{\mathrm{xy}}{ }^{2}}$

(6)

$\mathrm{f}_{\text {II }}=\frac{\mathrm{f}_{\mathrm{x}}+\mathrm{f}_{\mathrm{y}}}{2}-\sqrt{\left(\frac{\mathrm{f}_{\mathrm{x}}-\mathrm{f}_{\mathrm{y}}}{2}\right)^{2}+\mathrm{f}_{\mathrm{xy}}{ }^{2}}$

Tension reinforcement is not necessary if both principal forces are negative. In this case, the modulus of the compressive stress must satisfy $\left|f_{\| I} / t_{c}\right| \leq 0.85 f_{c}$, where $f_{c}$ is defined as the design value of concrete strength.

\subsection{Skew reinforcement design for concrete panels}

Figure 3 shows the forces per unit length in a skew reinforced concrete panel. The orientation angles of the primary and secondary reinforcements are $\alpha$ and $\beta$, respectively. The forces per unit length in the steel reinforcement are $f_{s \alpha}$ and $f_{s \beta}$. The compression force per unit length in the concrete struts between cracks is $f_{c \varphi}$. The orientation angle of the cracks is $\varphi$. All angles are defined by their corresponding counterclockwise rotations from the $x$-axis.

Figure 4 presents the force components of $f_{s a^{*}}$. The force decomposition of $f_{s \alpha}, f_{s \beta}$, and $f_{c \varphi}$ yields:

$\mathrm{f}_{\mathrm{c} \varphi} \cos ^{2} \varphi+\mathrm{f}_{\mathrm{s} \alpha} \cos ^{2} \alpha+\mathrm{f}_{\mathrm{s} \beta} \cos ^{2} \beta=\mathrm{f}_{\mathrm{x}}$

$\mathrm{f}_{\mathrm{c} \varphi} \sin ^{2} \varphi+\mathrm{f}_{\mathrm{s} \alpha} \sin ^{2} \alpha+\mathrm{f}_{\mathrm{s} \beta} \sin ^{2} \beta=\mathrm{f}_{\mathrm{y}}$

$\mathrm{f}_{\mathrm{c} \varphi} \cos \varphi \sin \varphi+\mathrm{f}_{\mathrm{s} \alpha} \cos \alpha \sin \alpha+\mathrm{f}_{\mathrm{s} \beta} \cos \beta \sin \beta=\mathrm{f}_{\mathrm{xy}}$

The inverse of (8) to (10) leads to:

$f_{c \varphi}=\frac{\left[-f_{x} \sin \beta \sin \alpha-f_{y} \cos \beta \cos \alpha+f_{x y} \sin (\beta+\alpha)\right]}{\sin (\beta-\varphi) \sin (\varphi-\alpha)}$

$f_{s \alpha}=\frac{\left[f_{x} \sin \beta \sin \varphi+f_{y} \cos \beta \cos \varphi-f_{x y} \sin (\beta+\varphi)\right]}{\sin (\beta-\alpha) \sin (\varphi-\alpha)}$

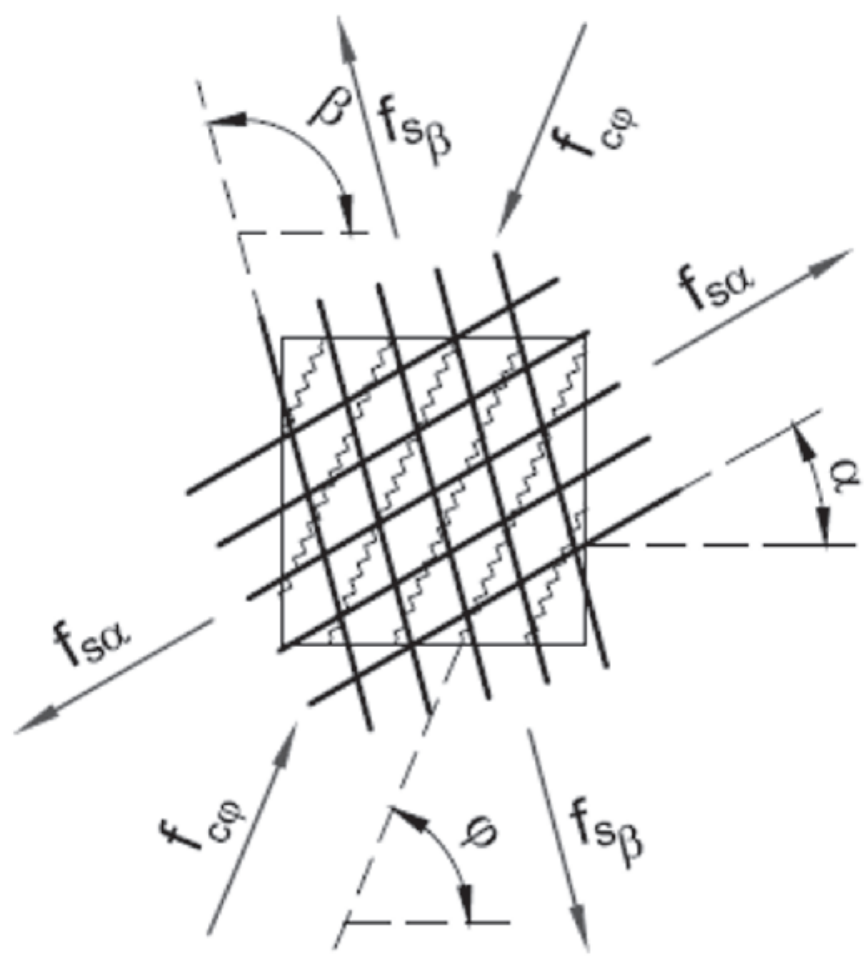

Figure 3

Forces per unit length in a skew reinforced concrete panel 

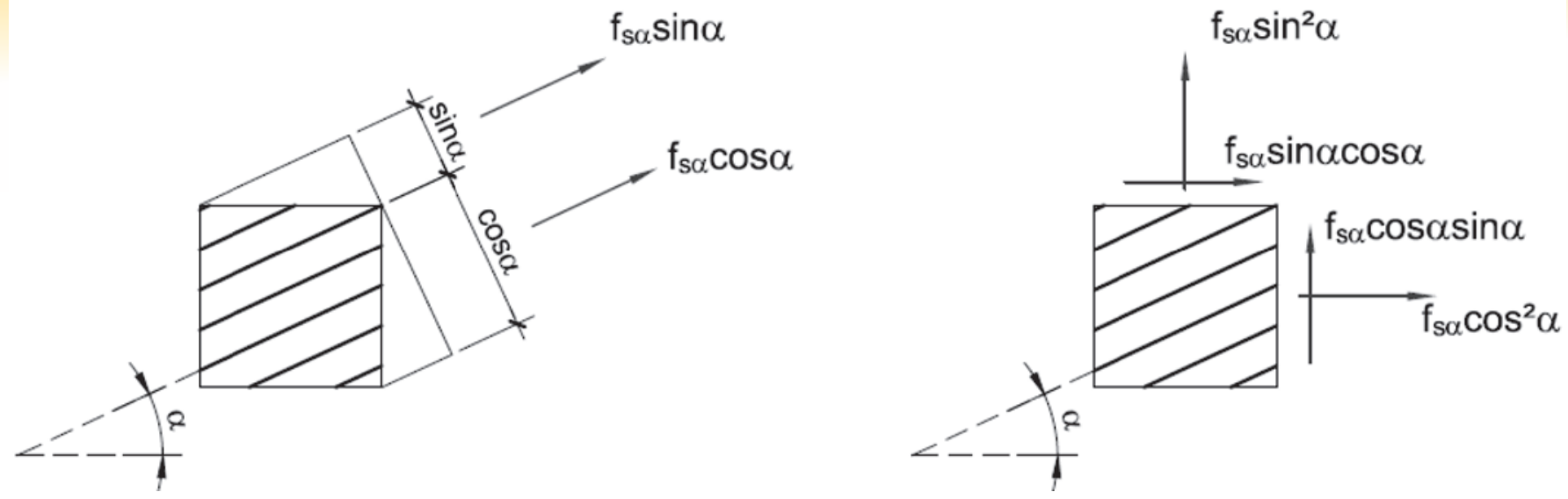

\section{Figure 4}

Force components of fs $\alpha$ in $\mathrm{x}$ and $\mathrm{y}$ directions

$f_{s \beta}=\frac{\left[f_{x} \sin \varphi \sin \alpha+f_{y} \cos \varphi \cos \alpha-f_{x y} \sin (\varphi+\alpha)\right]}{\sin (\beta-\alpha) \sin (\beta-\varphi)}$

The summation of both sides of (11), (12), and (13) yields:

$\mathrm{f}_{\mathrm{c} \varphi}+\mathrm{f}_{\mathrm{s} \alpha}+\mathrm{f}_{\mathrm{s} \beta}=\mathrm{f}_{\mathrm{x}}+\mathrm{f}_{\mathrm{y}}$

Considering (14) and $\mathrm{f}_{\mathrm{c \varphi}}<0$, minimizing the modulus $\left|\mathrm{f}_{\mathrm{c \varphi}}\right|$ yields the lowest sum of the steel forces $f_{s \alpha}+f_{s \beta}$. The following expressions are obtained by maximizing $f_{c \varphi}$ in (11):

$\varphi=\frac{\alpha+\beta}{2}$

if $-f_{x} \sin \beta \sin \alpha-f_{y} \cos \beta \cos \alpha+f_{x y} \sin (\beta+\alpha) \leq 0$

$$
\begin{aligned}
& \varphi=\frac{\alpha+\beta+\pi}{2} \\
& \text { if }-f_{x} \sin \beta \sin \alpha-f_{y} \cos \beta \cos \alpha+f_{x y} \sin (\beta+\alpha)>0
\end{aligned}
$$

(13) $\tan \varphi=\frac{f_{x y} \sin \beta-f_{y} \cos \beta}{f_{x} \sin \beta-f_{x y} \cos \beta}$

Equations (11), (13), and (15) define Case B. When $f_{s \beta}<0$, the substitution of $f_{s \beta}=0$ in (13) yields:

$\tan \varphi=\frac{f_{x y} \sin \alpha-f_{y} \cos \alpha}{f_{x} \sin \alpha-f_{x y} \cos \alpha}$

Equations (11), (12), and (17) define Case C.

The following equations yield the concrete stresses and the required steel reinforcement:

(15)

The design procedure defined by (11), (12), (13), and (15), denoted as Case $A$, yields $a_{s a}, a_{s \beta}$, and $f_{c \varphi}$ when $f_{s \alpha} \geq 0$ and $f_{s \beta} \geq 0$. When $f_{s \alpha}<$ 0 , the substitution of $\mathrm{f}_{\mathrm{sa}}=0$ in (12) yields :

$a_{s \beta}=\frac{f_{s \beta}}{f_{y d}}$

(a)

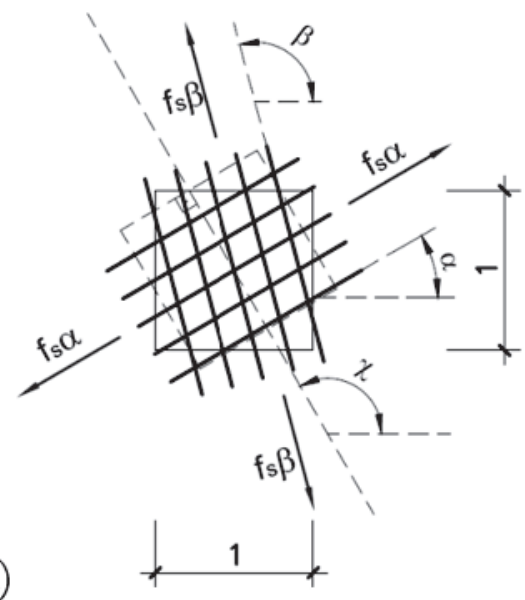

Figure 5

(a) Steel forces in directions $\alpha$ and $\beta$ and arbitrary direction $\chi$ (b) and (c) $f_{s \beta}$ component according to $\chi$ direction 


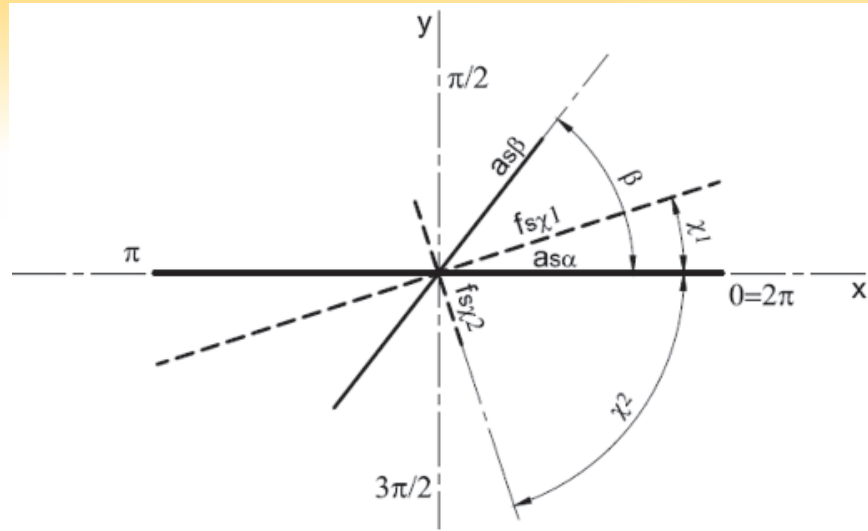

Figure 6

Maximum and minimum resultants $f_{s \times 1}$ and $f_{s \times 2}$ angles

where $f_{y d}$ is the design steel strength. The concrete stresses are limited to $\left|\sigma_{c \phi}\right|<0.6 f_{c d}$.

\subsection{Minimum reinforcement for skew meshes}

The minimum and maximum resultants of the steel forces $f_{s \alpha}$ and $f_{s \beta}$ are in orthogonal directions. For skew meshes, it is proposed that the minimum relation between secondary and main reinforcements must ensure that the minimum relation between minimum and maximum resultants is greater than $20 \%$. This assumption satisfies and generalizes the recommendations of ABNT NBR 6118:2014 [19] and other codes for orthogonal meshes. The resultant of the steel forces $\mathrm{f}_{\mathrm{s \alpha}}$ and $\mathrm{f}_{\mathrm{s} \beta}$ in an arbitrary direction $\chi$ (Figure 5 ) is expressed by:

$$
\mathrm{f}_{\mathrm{s} \chi}=\mathrm{f}_{\mathrm{s} \alpha} \cos ^{2}(\chi-\alpha)+\mathrm{f}_{\mathrm{s} \beta} \cos ^{2}(\chi-\beta)
$$

The angles of the maximum and minimum resultants $f_{s \times 1}$ and $f_{s \times 2}$ are $X_{1}$ and $X_{2}$, respectively (Figure 6 ). The following equation is obtained by setting the derivative of (21) equal to zero:

$\tan \left(2 \chi_{1}\right)=\tan \left(2 \chi_{2}\right)=\frac{\sin (2 \alpha)+r_{\beta \alpha} \sin (2 \beta)}{\cos (2 \alpha)+r_{\beta \alpha} \cos (2 \beta)}$ where $r_{\beta a}=f_{s \beta} / f_{s a}$ and $f_{s \alpha}$ is the force in the main reinforcement. Equation (22) confirms that $X_{1}$ and $X_{2}$ are orthogonal. The minimum relation between the force resultants $f_{s \times 1}$ and $f_{s \times 2}$ is defined by:

$\frac{f_{s \chi 2}}{f_{s \chi 1}} \geq 0.20$

The iterative solution of (21) to (23), presented in Rocha [20], yields the minimum relations $r_{\beta a, m i n}$ as a function of the skew reinforcement angle $\beta-\alpha$ (Table 1). The procedure yields $r_{\beta a, \text { min }}=1,00$ and $\mathrm{f}_{\mathrm{s} \beta, \min }=\mathrm{f}_{\mathrm{s \alpha}}$ for $\beta-\alpha=48.2^{\circ}$. No convergence is achieved for $\beta-\alpha$ $<48.2^{\circ}$.

The following theoretical study investigates the minimum reinforcement when $\beta-\alpha<48.2^{\circ}$, although this solution is not recommended for engineering practice. This approach defines $f_{s \alpha, \text { min }}=f_{s \beta, \text { min }}$ and $\mathrm{f}_{s \times 2}^{\prime} / \mathrm{f}_{s \times 1}^{\prime} \geq 0.20$, where $\mathrm{f}^{\prime}{ }_{s \times 1}$ is the maximum resultant for $\mathrm{f}_{\mathrm{s \beta}}=\mathrm{f}_{\mathrm{s \alpha}}$ and $\mathrm{f}_{\mathrm{s \times} 2}^{\prime}$ is the minimum resultant for $\mathrm{f}_{\mathrm{s} \beta, \min }=\mathrm{f}_{\mathrm{s \alpha , \operatorname {min }}}=\mathrm{kf}_{\mathrm{sa}}$.

$\mathrm{f}_{\mathrm{s} \chi 1}^{\prime}=2 \mathrm{f}_{\mathrm{s \alpha}} \cos ^{2}\left(\frac{\beta-\alpha}{2}\right)$

$\mathrm{f}_{\mathrm{sx} 2}^{\prime}=2 \mathrm{kf}_{\mathrm{s} \alpha} \sin ^{2}\left(\frac{\beta-\alpha}{2}\right)$

The condition $\mathrm{f}_{\mathrm{s} 2}^{\prime} / \mathrm{f}_{\mathrm{s} \div 1}^{\prime} \geq 0.20,(24)$, and (25) yield:

$k=0.20 \cot ^{2} \frac{\beta-\alpha}{2}$

The values of $k$ (Table 2) increase rapidly when reducing the angle between reinforcements. This conclusion confirms the recommendation that $\beta-\alpha$ should be greater than $48.2^{\circ}$.

The force associated with the minimum reinforcement ratio is denoted as $f_{s, \text { min }}$. The conditions $f_{s \alpha, \text { min }} \geq f_{s, \text { min }}, f_{s \beta, \text { min }} \geq f_{s, \text { min }}$, and $f_{s x 2 \text {, min }}$ $\geq \mathrm{f}_{\mathrm{s}, \text { min }}$ and (21) and (22) yield $\mathrm{f}_{\mathrm{s} \alpha \text {, min }}$ and $\mathrm{f}_{\mathrm{s}, \text { min }}$ by using an optimization procedure that is available in standard spreadsheets. The minimum reinforcement ratios in the primary direction $\rho_{\mathrm{s} \alpha}$ are presented in Table 3 . Figure 7 presents the corresponding reinforcement ratio $\rho_{s \beta, \min }$ as a function of $\rho_{\mathrm{s} \alpha}$ and $\beta-\alpha$. The minimum

Table 1

Minimum secondary reinforcement for different skew angles

\begin{tabular}{|c|c|c|c|c|c|c|c|c|c|c|c|}
\hline$\beta-\alpha\left(^{\circ}\right)$ & 90.0 & 85.0 & 80.0 & 75.0 & 70.0 & 65.0 & 60.0 & 55.0 & 50.0 & 48.2 & 45.0 \\
\hline$r_{\beta \alpha^{*}} \min$ & 0.200 & 0.202 & 0.210 & 0.222 & 0.243 & 0.275 & 0.325 & 0.414 & 0.625 & 1.000 & $1.000^{*}$ \\
\hline
\end{tabular}

\section{Table 2}

k factor for different skew angles

\begin{tabular}{|c|c|c|c|c|c|c|c|c|c|c|c|}
\hline$\beta-\alpha\left(^{\circ}\right)$ & $\leq 48.2$ & 45.0 & 40.0 & 35.0 & 30.0 & 25.0 & 20.0 & 15.0 & 10.0 & 5.0 & 0.0 \\
\hline$k$ & 1.000 & 1.166 & 1.510 & 2.012 & 2.786 & 4.069 & 6.433 & 11.539 & 26.129 & 104.92 & $\infty$ \\
\hline
\end{tabular}

\section{Table 3}

Minimum reinforcement ratio for different skew angles

\begin{tabular}{|c|c|c|c|c|c|c|c|c|c|c|c|c|}
\hline & $\beta-\alpha\left(^{\circ}\right)$ & 90.0 & 85.0 & 80.0 & 75.0 & 70.0 & 65.0 & 60.0 & 55.0 & 50.0 & 48.2 & 45.0 \\
\hline \multirow{4}{*}{$e^{\frac{\varepsilon}{c^{5}}}$} & $\leq \mathrm{C} 30$ & $0.150 \%$ & $0.164 \%$ & $0.182 \%$ & $0.202 \%$ & $0.228 \%$ & $0.260 \%$ & $0.300 \%$ & $0.352 \%$ & $0.420 \%$ & $0.450 \%$ & $0.512 \%$ \\
\hline & C35 & $0.164 \%$ & $0.180 \%$ & $0.198 \%$ & $0.221 \%$ & $0.249 \%$ & $0.284 \%$ & $0.328 \%$ & $0.385 \%$ & $0.459 \%$ & $0.492 \%$ & $0.560 \%$ \\
\hline & C40 & $0.179 \%$ & $0.196 \%$ & $0.217 \%$ & $0.241 \%$ & $0.272 \%$ & $0.310 \%$ & $0.358 \%$ & $0.420 \%$ & $0.501 \%$ & $0.537 \%$ & $0.611 \%$ \\
\hline & C45 & $0.194 \%$ & $0.212 \%$ & $0.235 \%$ & $0.262 \%$ & $0.295 \%$ & $0.336 \%$ & $0.388 \%$ & $0.455 \%$ & $0.543 \%$ & $0.582 \%$ & $0.662 \%$ \\
\hline
\end{tabular}




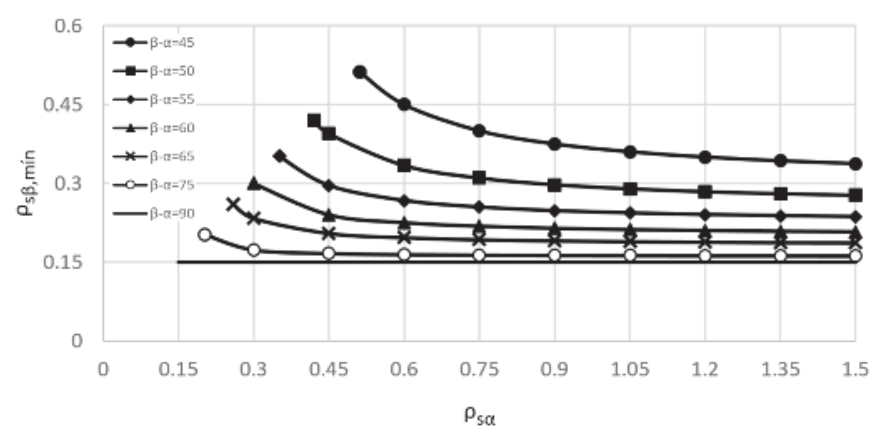

Figure 7

Minimum reinforcement ratios for $f_{c k} \leq 30 \mathrm{MPa}$

reinforcement ratio $\rho_{s \beta, \min }$ decreases with increasing $\rho_{\mathrm{s} \alpha}$ for $\rho_{\mathrm{s} \alpha}>\rho_{\mathrm{s} \alpha, \min }$.

\subsection{Transverse shear forces}

Schulz [11] and Marti [21] define the principal shear force $F_{\theta z}$ as:

$\mathrm{F}_{\theta \mathrm{z}}=\sqrt{\mathrm{F}_{x z}^{2}+\mathrm{F}_{y z}^{2}}$
When shear reinforcement is necessary, the upper and lower panels must consider the following additional tension forces:

$$
\begin{aligned}
& \mathrm{nf}_{\mathrm{x}}=\frac{\mathrm{F}_{x z}^{2}}{\mathrm{~F}_{\theta z}} \frac{\cot \varnothing}{2} \\
& \mathrm{nf}_{\mathrm{y}}=\frac{\mathrm{F}_{y z}^{2}}{\mathrm{~F}_{\theta z}} \frac{\cot \varnothing}{2} \\
& \mathrm{nf}_{\mathrm{xy}}=\frac{\mathrm{F}_{\mathrm{xz}}}{\mathrm{F}_{\mathrm{yz}}} \frac{\cot \varnothing}{2}
\end{aligned}
$$

where $\varnothing$ is the angle of the transverse struts. The additional tension forces are equivalent to the staggering rule.

\section{Examples}

The design procedure is applied to flat bridges with and without lateral beams and decks of multi-girder bridges. Figures 8 and 9 present the typical cross section of the flat bridges with and without lateral beams, respectively.

Figure 10 presents the cross section of the studied multi-girder bridges. Each structural system is analyzed using finite element models by considering skew angles of $0^{\circ}, 15^{\circ}, 30^{\circ}$, and $45^{\circ}$.

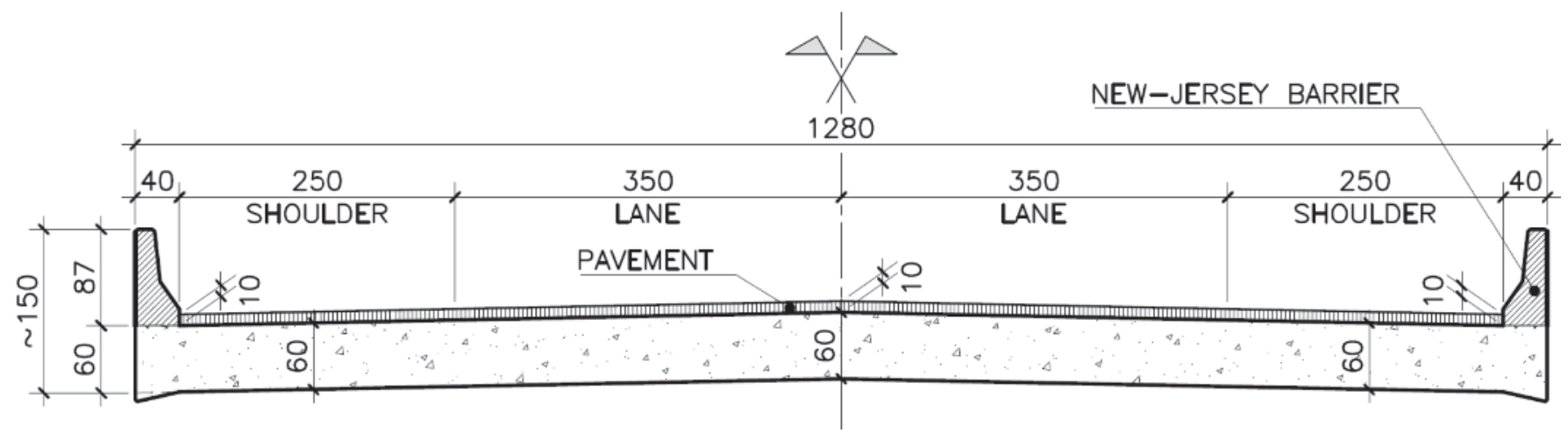

\section{Figure 8}

Typical cross section of flat bridges without lateral beams

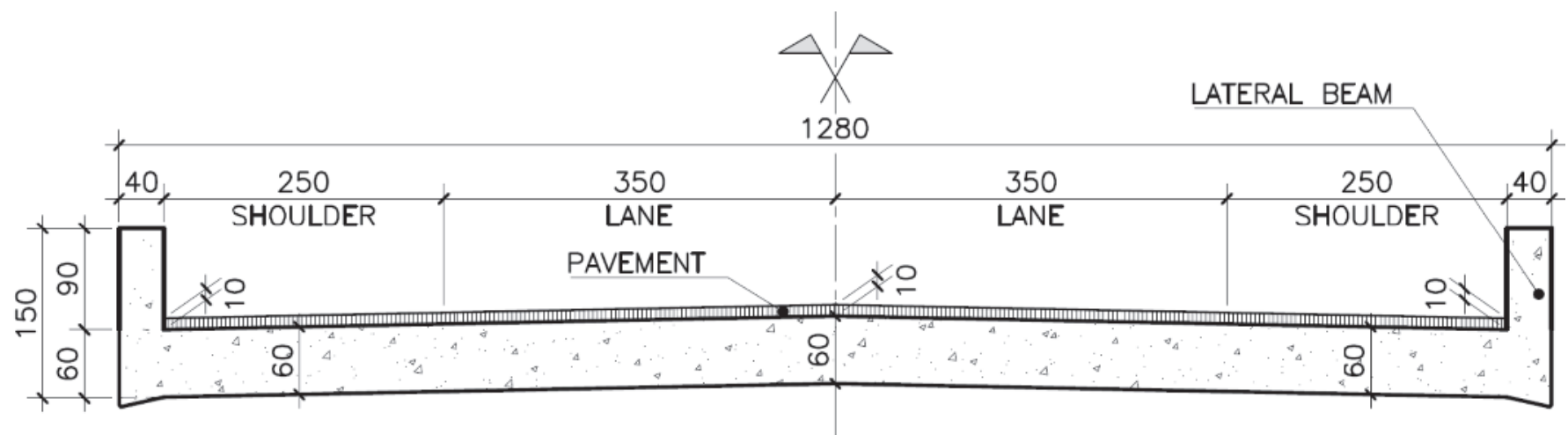

\section{Figure 9}

Typical cross section of flat bridges with lateral beams 


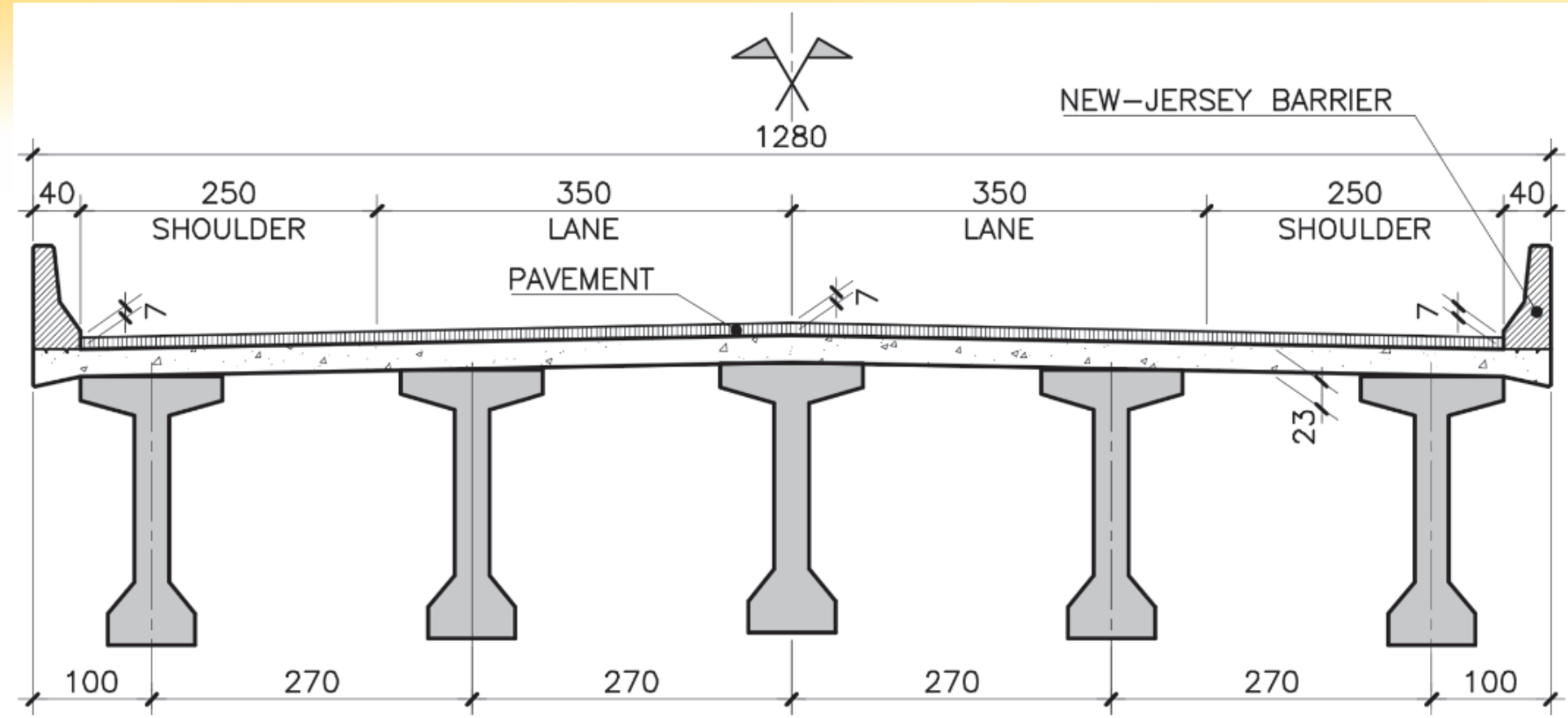

Figure 10

Typical cross section of multi-girder bridges

(a)
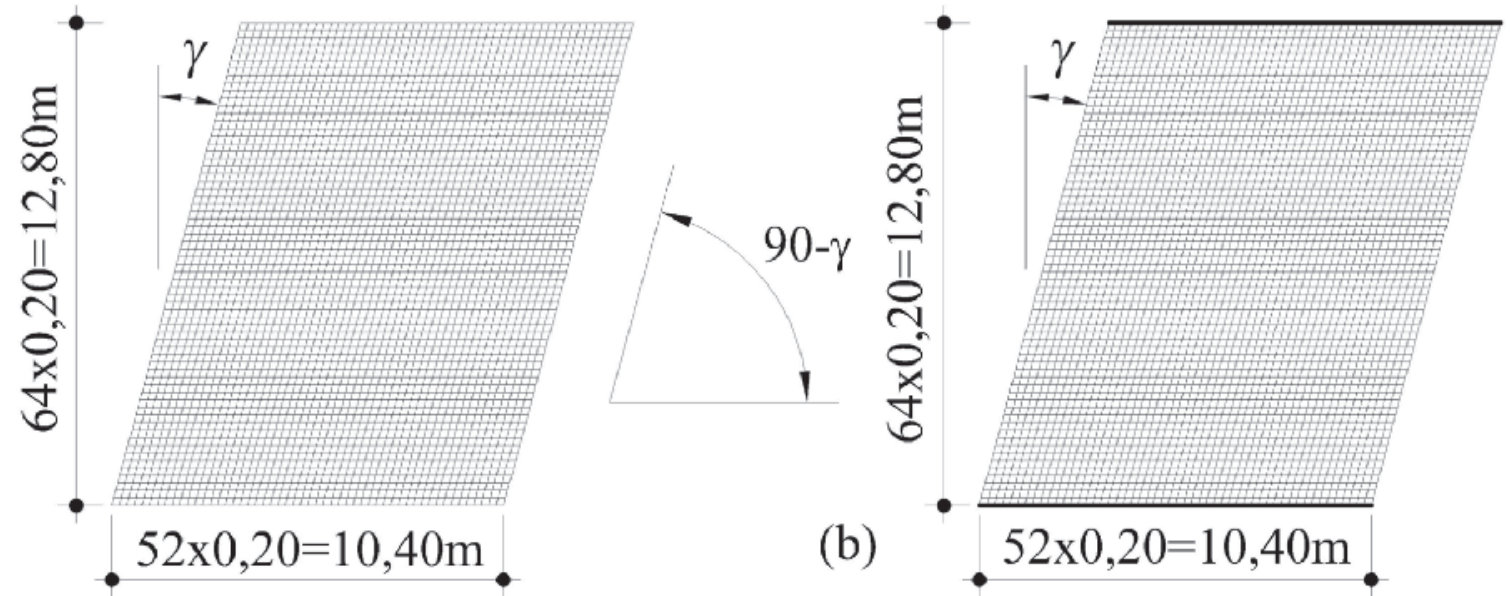

(c)

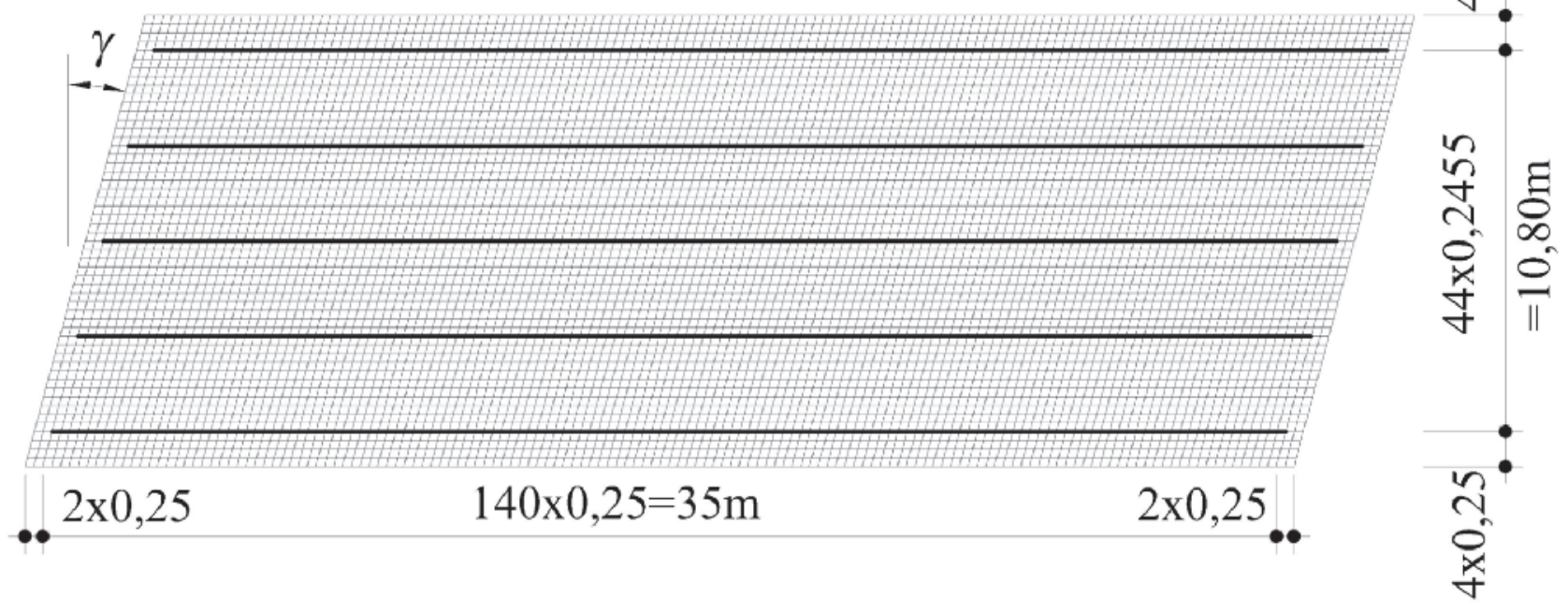

Figure 11

Finite element models for (a) flat bridges without lateral beams, (b) flat bridges with lateral beams, and (c) multi-girder bridges 

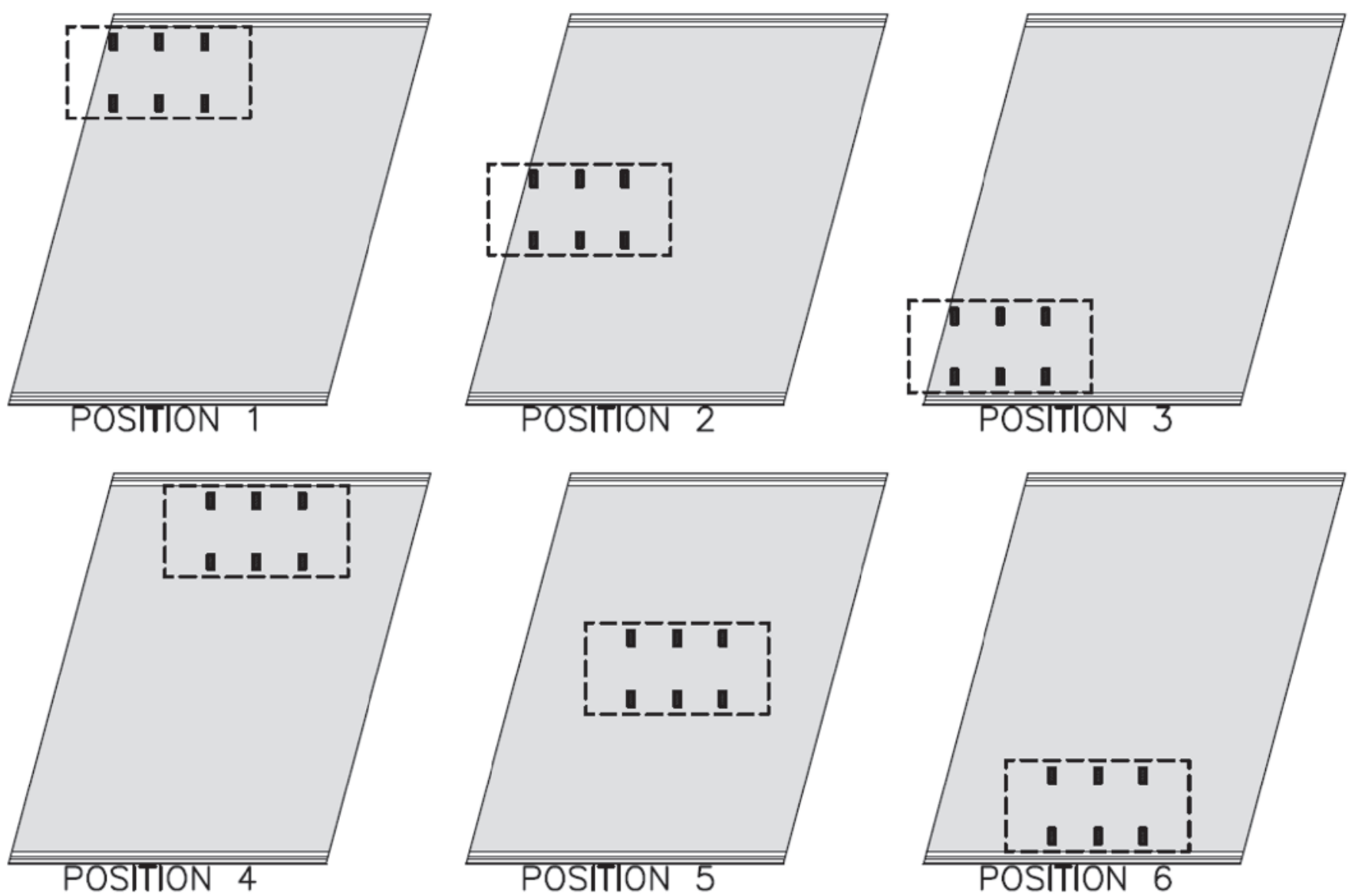

Figure 12

Vehicle positions for flat bridges
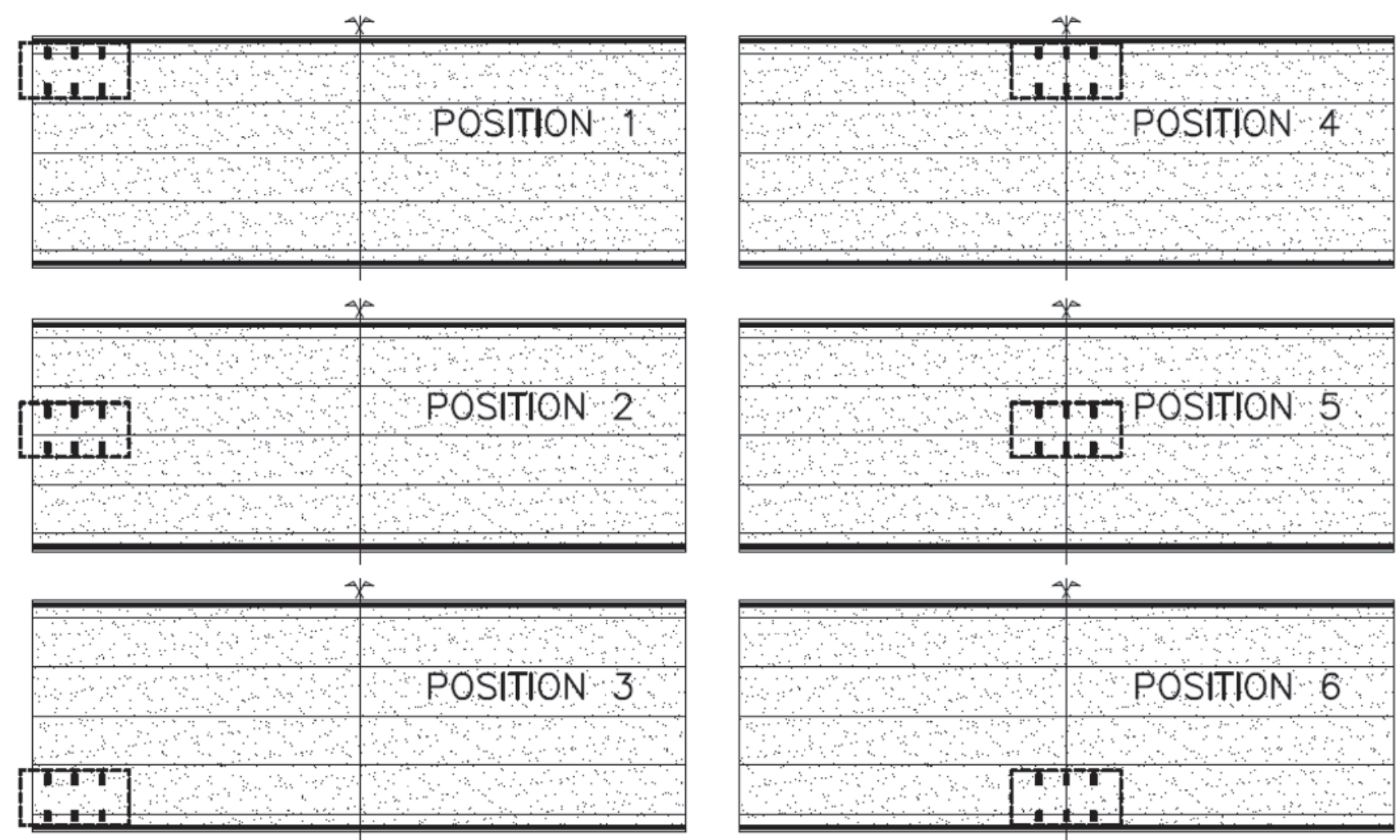

Figure 13

Vehicle positions for multi-girder bridges 


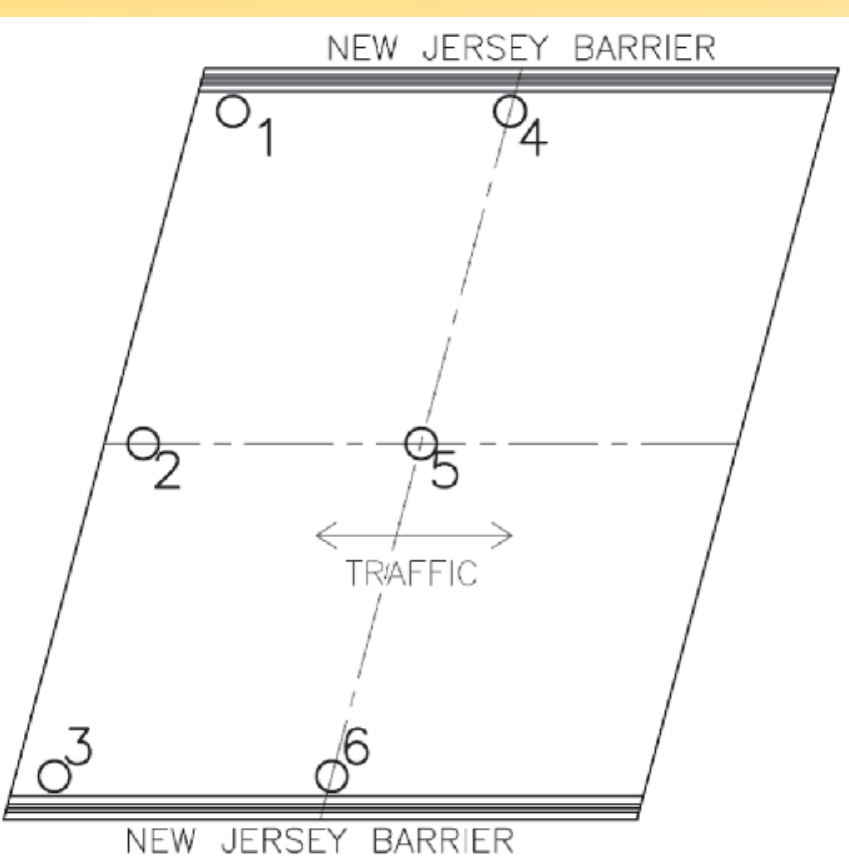

Figure 14

Critical locations for reinforcement design on flat bridges

The flat bridges are $0.60 \mathrm{~m}$ in height and have a single $10.4 \mathrm{~m}$ span in the direction of traffic. The multi-girder bridges have five concrete main girders with a $35 \mathrm{~m}$ free-span and a $0.23 \mathrm{~m}$ thick concrete deck. The width of all bridges is $12.8 \mathrm{~m}$ comprising two $3.6 \mathrm{~m}$ main lanes, shoulders, and New Jersey barriers. On the flat bridges with lateral beams, the barriers are exchanged for lateral beams $1.5 \mathrm{~m}$ in depth (Figure 9).

The in-plane reinforcement is determined by the design procedure proposed for skew meshes. The transverse shear reinforcement is verified for the principal transverse shear force. The discussion is limited to the in-plane reinforcement and does not consider service limit states, fatigue, and girders' prestress.

The internal forces are evaluated by linear elastic analysis of finite element models. The mesh patterns of the flat bridge and girder bridge decks are $0.20 \mathrm{~m} \times 0.20 \mathrm{~m}$ and $0.25 \mathrm{~m} \times 0.25 \mathrm{~m}$, respectively (Figure 11). Thin-shell elements are used for the slabs and frame elements are used for the beams, and the models are processed on SAP 2000 [22] software. The insertion points of the frame elements are properly defined for the correct evaluation of the in-plane normal forces. The $x$ local axis of the shell elements is defined in the direction of the longitudinal reinforcement and traffic; thus, $\alpha$ is always zero and $\beta$ is defined as $\beta=90^{\circ}-\gamma$, where $y$ is the skew angle (Figure 11).

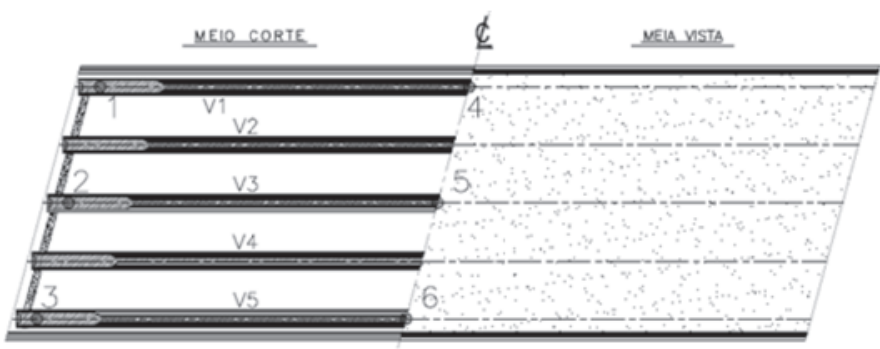

C35 concrete and CA-50 steel are used. The Poisson ratio is considered to be 0.20 and the elasticity modulus of concrete according to ABNT NBR 6118:2014 [19] is adopted by considering granite as coarse aggregate.

The dead loads include the self-weight, pavement, recapping load, and barriers' weight. The analysis of the girder bridges did not consider the self-weight of the main girders because they are usually pre-cast and their self-weight does not generate internal forces on the slabs. The moving load is defined according to ABNT NBR 7188:2013 [23] Class 45 considering the number of lanes and vertical and additional impact factors. Figures 12 and 13 show the predefined vehicle positions. The dimensions of the shell elements are defined to favor the distribution of the axle loads projected on the mid-plane of the slabs.

The loads are combined according to ABNT NBR 8681:2003 [24]. Figures 14 and 15 present the critical locations for the reinforcement design.

Shear reinforcement is evaluated according to ABNT NBR $6118: 2014$ [19]. Flat bridges require shear reinforcement and the in-plane reinforcement is neglected in the evaluation of the maximum resistant shear force because the reinforcement is rarely placed in the same direction as the principal shear force. In girder bridges, the transverse shear force evaluated by the finite element models and complementary manual verifications do not demand shear reinforcement.

The total steel mass is calculated considering the schematic rebar detailing presented in Rocha [20].

\section{Results and discussion}

\subsection{Flat bridges without lateral beams}

Table 4 presents the reinforcement and concrete stresses at critical points of the flat bridges without lateral beams.

The skew angles increase the necessary amount of reinforcement and compressive concrete stresses. The bottom rebar meshes are denser and especially affected by the skew angle. The amount of reinforcement has reduced at the acute edges.

The $30^{\circ}$ and $45^{\circ}$ flat bridges do not meet the allowable concrete stress neither by using $k_{c}=0.3$ and $k_{z}=0.9$, as recommended by Leonhardt [16]), nor by adjusting the panel thicknesses and lever arm. The $30^{\circ}$ and $45^{\circ}$ flat bridges require concrete strength higher than $35 \mathrm{MPa}$.

The obtuse edges have concentrated twisting moments and shear forces. Shear forces in other parts of the slab are not significantly affected by the distortion of the deck.

Skew decks increase the bending moment $M_{x}$ and torsional moment $M_{x y}$, which lead to higher amount of reinforcement (Table 5). The minimum reinforcement has little influence on the total amount of steel.

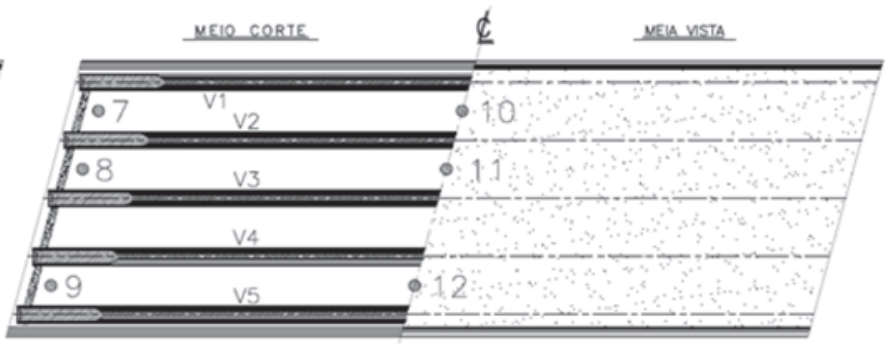

Figure 15

Critical locations for reinforcement design on multi-girder bridges 
Table 4

Reinforcement area and concrete stresses on flat bridges without lateral beams

\begin{tabular}{|c|c|c|c|c|c|c|c|c|}
\hline \multirow[b]{2}{*}{ Point } & \multicolumn{4}{|c|}{$a_{s \alpha, \text { sup,max }}\left(\mathrm{cm}^{2} / \mathrm{m}\right) / a_{s \alpha, \text { inf,max }}\left(\mathrm{cm}^{2} / \mathrm{m}\right)$} & \multicolumn{4}{|c|}{$a_{s \beta, \text { sup, max }}\left(\mathrm{cm}^{2} / \mathrm{m}\right) / a_{s \beta, \text { inf, max }}\left(\mathrm{cm}^{2} / \mathrm{m}\right)$} \\
\hline & $\gamma=0^{\circ}$ & $\gamma=15^{\circ}$ & $\gamma=30^{\circ}$ & $\gamma=45^{\circ}$ & $\gamma=0^{\circ}$ & $\gamma=15^{\circ}$ & $\gamma=30^{\circ}$ & $\gamma=45^{\circ}$ \\
\hline 1 & $0 / 12.57$ & $4.1 / 27.27$ & $8.29 / 40.78$ & $13.5 / 48.96$ & $3.69 / 5.62$ & $8.28 / 17.18$ & $8.44 / 35.56$ & $2.8 / 52.98$ \\
\hline 2 & $0 / 8.17$ & $0 / 9.15$ & $0.67 / 18.68$ & $4.92 / 25.88$ & $0.62 / 3.27$ & $0.94 / 5.59$ & $5.72 / 12.97$ & $11.62 / 23$ \\
\hline 3 & $0 / 12.57$ & $0 / 7.89$ & $0 / 4.03$ & $0 / 2.54$ & $3.69 / 5.62$ & $0.87 / 1.85$ & $0.13 / 1.42$ & $0.12 / 0.76$ \\
\hline 4 & $0 / 35.86$ & $0 / 41.56$ & $0 / 44.77$ & $0 / 46.8$ & $0 / 2.29$ & $0 / 8.05$ & $0.61 / 13.34$ & $0.98 / 18.43$ \\
\hline 5 & $0 / 30.24$ & $0 / 38.33$ & $0 / 47.41$ & $0 / 58.47$ & $0 / 7.89$ & $0 / 17.05$ & $0 / 29.63$ & $0 / 46.2$ \\
\hline 6 & $0 / 35.86$ & $0 / 41.56$ & $0 / 44.77$ & $0 / 46.8$ & $0 / 2.29$ & $0 / 8.05$ & $0.61 / 13.34$ & $0.98 / 18.43$ \\
\hline
\end{tabular}

\begin{tabular}{|c|c|c|c|c|c|c|c|c|}
\hline \multirow[b]{2}{*}{ Point } & \multicolumn{4}{|c|}{$\left|\sigma_{c \phi, \text { sup }}\right|_{\text {max }}(\mathrm{MPa})$} & \multicolumn{4}{|c|}{$\left|\sigma_{c \phi, i n f}\right|_{\max }(\mathrm{MPa})$} \\
\hline & $\gamma=0^{\circ}$ & $\gamma=15^{\circ}$ & $\gamma=30^{\circ}$ & $\gamma=45^{\circ}$ & $\gamma=0^{\circ}$ & $\gamma=15^{\circ}$ & $\gamma=30^{\circ}$ & $\gamma=45^{\circ}$ \\
\hline 1 & -2.76 & -4.39 & -4.79 & -3.64 & -2.68 & -8.5 & -17.33 & -24.69 \\
\hline 2 & -1.8 & -1.75 & -2.11 & -4.3 & -1.27 & -2.26 & -5.51 & -10.54 \\
\hline 3 & -2.76 & -1.94 & -1.04 & -0.46 & -2.68 & -0.67 & -0.65 & -0.45 \\
\hline 4 & -9.2 & -8.77 & -7.17 & -5.18 & -0.19 & -3.5 & -7.54 & -11.53 \\
\hline 5 & -7.76 & -7.34 & -6.12 & -4.41 & -0.21 & -4.94 & -12 & -21.11 \\
\hline 6 & -9.2 & -8.77 & -7.17 & -5.18 & -0.19 & -3.5 & -7.54 & -11.53 \\
\hline
\end{tabular}

\subsection{Flat bridges with lateral beams}

Table 6 presents the reinforcement and concrete stresses at the critical locations of flat bridges with lateral beams. The skew angle increases the bottom reinforcement as in bridges without beams. The lateral beams reduce the influence of the skew angle in the upper mesh and the total amount of reinforcement.

The $45^{\circ}$ bridge requires concrete strength higher than $35 \mathrm{MPa}$ because the adjustment of panel thicknesses and lever arms does not reduce concrete stresses significantly.

The model automatically determines the effective flange width and the shear reinforcement between the web and flange by considering the offset between the slab mid-plane and the beam axis.

Table 7 presents the total amount of reinforcement of flat bridges with lateral beams. The lateral beams replace the barriers and reduces the total amount of reinforcement.

\subsection{Multi-girder bridges}

Table 8 presents the reinforcement and concrete stresses in

\section{Table 5}

Total steel mass and ratios for flat bridges without lateral beams

\begin{tabular}{|c|c|c|c|c|}
\hline \multirow{2}{*}{$\gamma$} & \multirow{2}{*}{$\begin{array}{c}\text { Total steel } \\
\text { mass (kg) }\end{array}$} & \multicolumn{2}{|c|}{ Ratios } & \multirow{2}{*}{$\mathbf{P}_{\mathbf{P}_{\mathbf{0}^{\circ}}}$} \\
\cline { 3 - 4 } & & $\mathbf{k g} / \mathbf{m}^{2}$ & $\mathbf{k g} / \mathbf{m}^{3}$ & \\
\hline $0^{\circ}$ & 7800 & 59 & 98 & 1.00 \\
\hline $15^{\circ}$ & 10077 & 76 & 126 & 1.29 \\
\hline $30^{\circ}$ & 15153 & 114 & 190 & 1.94 \\
\hline $45^{\circ}$ & 23437 & 176 & 293 & 3.00 \\
\hline
\end{tabular}

multi-girder bridges considering $k_{c}=0.3$ and $k_{z}=0.9$. The concrete stresses exceed the allowable values because the slab is the girders' compression zone. Table 9 presents the results using the alternative indicated in Eurocode 2 [17], with thicker panels and correspondingly reduced lever arms (Figure 16). The concrete stresses of $0^{\circ}, 15^{\circ}$, and $30^{\circ}$ bridges are less than or equal to the allowable limits. The $45^{\circ}$ bridge requires $\mathrm{C} 60$ concrete or a $0.30 \mathrm{~m}$ thick slab. The skew geometry changes the twisting moments $M_{x y}$ and the normal forces $F_{y}$ in the transverse direction $\left(90^{\circ}\right.$ to traffic). The increase in the amount of steel (Table 10) is associated with the effective necessary reinforcement because the minimum ratios have little influence on the total results.

The reinforcement design of orthogonal meshes based on the results of the skewed models yield variable rebar distributions that does not significantly increase the total amount of reinforcement. Orthogonal and skew meshes are possible alternatives for skewed multi-girder bridges that require case by case evaluation. The first is more economical and the second simplifies rebar detailing and execution.

\section{Final considerations}

This paper discusses the reinforcement design of two-dimensional concrete structures with skew rebar meshes whose directions are not aligned with the principal internal forces. The in-plane internal forces include two normal forces, one tangential force, two bending moments, and one twisting moment. The analysis includes two transverse shear forces in the direction normal to the element midplane. The smeared cracking model, equilibrium considerations, and plasticity approach yield the design equations of the skew reinforcement.

Design examples of flat bridges without beams, flat bridges with lateral beams, and multi-girder bridges are presented for skew angles of $0^{\circ}, 15^{\circ}, 30^{\circ}$, and $45^{\circ}$.

The flat bridges without lateral beams require upper reinforcement, 
Table 6

Reinforcement area and concrete stresses on flat bridges with lateral beams

\begin{tabular}{|c|c|c|c|c|c|c|c|c|}
\hline \multirow[b]{2}{*}{ Point } & \multicolumn{4}{|c|}{$a_{s \alpha, \text { sup, max }}\left(\mathrm{cm}^{2} / \mathrm{m}\right) / a_{s \alpha, \text { inf, },}\left(\mathrm{cm}^{2} / \mathrm{m}\right)$} & \multicolumn{4}{|c|}{$a_{s \beta, \text { sup, max }}\left(\mathrm{cm}^{2} / \mathrm{m}\right) / a_{s \beta, \text { in, } \text { max }}\left(\mathrm{cm}^{2} / \mathrm{m}\right)$} \\
\hline & $\gamma=0^{\circ}$ & $\gamma=15^{\circ}$ & $\gamma=30^{\circ}$ & $\gamma=45^{\circ}$ & $\gamma=0^{\circ}$ & $\gamma=15^{\circ}$ & $\gamma=30^{\circ}$ & $\gamma=45^{\circ}$ \\
\hline 1 & $9.26 / 9.34$ & $11.79 / 9.2$ & $9.64 / 7.64$ & $0.43 / 4.79$ & $6.63 / 2.35$ & $10.09 / 1.19$ & $10.78 / 0$ & $3.75 / 0$ \\
\hline 2 & $0 / 5.12$ & $0 / 8.34$ & $0.22 / 18.32$ & $2.37 / 25.92$ & $0 / 0$ & $0 / 3.97$ & $0 / 15.62$ & $3.57 / 26.23$ \\
\hline 3 & $9.26 / 9.34$ & $6.83 / 8.37$ & $5.09 / 5.77$ & $1.36 / 4.12$ & $6.63 / 2.35$ & $4.27 / 2.72$ & $3.17 / 2.21$ & $0 / 0.59$ \\
\hline 4 & $5.82 / 24.8$ & $7.5 / 30.12$ & $6.4 / 37.76$ & $2.82 / 47.9$ & $7.81 / 5.69$ & $4.2 / 10.29$ & $5.86 / 17.36$ & $6.66 / 28.31$ \\
\hline 5 & $0 / 18.05$ & $0 / 24.48$ & $0 / 34.51$ & $0 / 52.08$ & $0 / 14.37$ & $0 / 20.02$ & $0 / 27.81$ & $0 / 43.09$ \\
\hline 6 & $5.82 / 24.8$ & $7.5 / 30.12$ & $6.4 / 37.76$ & $2.82 / 47.9$ & $7.81 / 5.69$ & $4.2 / 10.29$ & $5.86 / 17.36$ & $6.66 / 28.31$ \\
\hline
\end{tabular}

\begin{tabular}{|c|c|c|c|c|c|c|c|c|}
\hline & \multicolumn{4}{|c|}{$\left|\sigma_{c \phi, \text { sup }}\right|_{\max }(\mathrm{MPa})$} & \multicolumn{4}{|c|}{$\left|\sigma_{c \phi, i n f}\right|_{\max }(M P a)$} \\
\hline Point & $\gamma=0^{\circ}$ & $\gamma=15^{\circ}$ & $\gamma=30^{\circ}$ & $\gamma=45^{\circ}$ & $\gamma=0^{\circ}$ & $\gamma=15^{\circ}$ & $\gamma=30^{\circ}$ & $\gamma=45^{\circ}$ \\
\hline 1 & -5.03 & -6.75 & -6.55 & -2.04 & -2 & -2.01 & -1.59 & -1.33 \\
\hline 2 & -1.52 & -1.55 & -1.47 & -1.92 & -0.65 & -1.96 & -6.67 & -11.73 \\
\hline 3 & -5.03 & -3.44 & -1.96 & -0.67 & -2 & -1.38 & -0.53 & -0.51 \\
\hline 4 & -0.52 & -1.66 & -2.01 & -1.8 & -0.2 & -2.62 & -6.95 & -13.47 \\
\hline 5 & -5.3 & -5.28 & -4.98 & -4.1 & -0.19 & -3.41 & -8.97 & -18.86 \\
\hline 6 & -0.52 & -1.66 & -2.01 & -1.8 & -0.2 & -2.62 & -6.95 & -13.47 \\
\hline
\end{tabular}

especially for higher skew angles. The maximum longitudinal reinforcement on the $0^{\circ}, 15^{\circ}$, and $30^{\circ}$ bridges are found at the free edges. The maximum main reinforcement on the $45^{\circ}$ bridge is observed at the center of the slab. The skew geometry and rebar meshes significantly increase the secondary reinforcement and the required steel area in the obtuse edges. Concrete stresses are critical in the bottom panel of obtuse edges.

The use of lateral beams reduces the required steel area but does not change the location of the maximum values. Lateral beams reduce the internal forces at obtuse edges. The required steel area in obtuse and acute edges yield similar results. Concrete stresses are higher in the bottom panel on the middle of the span. Lateral beams significantly reduce the total mass of steel and compression stresses in the concrete.

The maximum bottom and upper reinforcement of multi-girder decks are observed between the girders on the middle of the span and over the girders next to the supports, respectively. Concrete stresses are critical in the middle of the span because the slab is the girders' compression zone. Multi-girder bridges decks yield in-plane normal and shear forces that are not considered by the flexural approach proposed by Wood, Mills, and Armer [3] [4]. Baumann's [5] two-panel model accounts for in-plane normal and shear forces, bending moments, and twisting moments.

Skew reinforcement meshes increase the required amount of steel and concrete compressive stresses. Even small skew angles should not be neglected. The deck slab often requires higher thickness or concrete strength because the adjustment of the panel thicknesses and lever arm does not always yield allowable concrete stresses.

The proposed minimum reinforcement and minimum secondary reinforcement extend the orthogonal mesh criteria to skew reinforcement in terms of principal steel forces. The minimum relation between the principal steel forces indicates that the skew angle of the reinforcement meshes should be limited.

\section{Bibliography}

[1] FALCONER, B. H. - Theory of the stresses induced in reinforced concrete by applied two-dimensional stress, $\mathrm{ACl}$ Journal, vol. 53(9), 1956, pp. 277-294.

[2] NIELSEN, M. P. - Yield conditions for reinforced concrete shells in the membrane state, Non Classical Shell Problems: IASS Symposium, W. Olszak, ed., North-Holland, Amsterdam, 1964, pp. 1030-1040.

[3] WOOD, R. H. - The reinforcement of slabs in accordance with a pre-determined field of moments, Concrete, The Journal of the Concrete Society, vol. 2, no. 2, 1968, pp. 69-76.

[4] MILLS, H. B., ARMER, G. S. T., WOOD, R. H. - The reinforcement of slabs in accordance with a pre-determined field of moments - Correspondence, Concrete, The Journal of the Concrete Society, vol. 2, no. 8, 1968, pp. 319-320.

[5] BAUMANN, T. - Tragwirkung orthogonaler Bewehrungsnetze beliebiger Richtung in Flächentragwerken aus Stahlbeton, Deutscher Ausschuss für Stahlbeton, no. 217, Berlin, 1972, pp. 1-53.

\section{Table 7}

Total steel mass and ratios for flat bridges with lateral beams

\begin{tabular}{|c|c|c|c|c|}
\hline \multirow{2}{*}{$\gamma$} & \multirow{2}{*}{$\begin{array}{c}\text { Total steel } \\
\text { mass (kg) }\end{array}$} & \multicolumn{2}{|c|}{ Ratios } & \multirow{2}{*}{$\mathbf{P}_{\mathbf{P}_{0^{\circ}}}$} \\
\cline { 3 - 4 } & $\mathbf{k g} / \mathbf{m}^{2}$ & $\mathbf{k g} / \mathbf{m}^{3}$ & \\
\hline $0^{\circ}$ & 6648 & 50 & 83 & 1.00 \\
\hline $15^{\circ}$ & 8303 & 62 & 104 & 1.25 \\
\hline $30^{\circ}$ & 12538 & 94 & 157 & 1.89 \\
\hline $45^{\circ}$ & 21271 & 160 & 266 & 3.20 \\
\hline
\end{tabular}


[6] Comité Euro-International du Béton and Fédération Internationale de la Précontrainte - Bul. d'Information 141: CEB/ FIP manual on bending and compression, Construction Press, London, 1982.

[7] MITCHELL, D., COLLINS, M. P. - Diagonal compression field theory - A rational model for structural concrete in pure torsion, ACl Journal, vol. 71(8), 1974, pp. 396-408.

[8] SCHULZ, M. - Design of reinforced concrete plates and shells, Proceedings of the Conference on Structural Analysis and Design of Nuclear Power Plants, Universidade Federal do Rio Grande do Sul, Porto Alegre, 1984, pp. 115-127.

[9] VECCHIO, F. J., COLLINS, M. P. - The modified compression field theory for reinforced concrete elements subjected to shear, ACl Journal, vol. 83(2), pp. 219-231.

[10] POLAK, M. A., VECCHIO, F. J. - Nonlinear analysis of reinforced concrete shells" Publication No. 93-03, Dept. of Civil Engineering, Univ. of Toronto, Toronto, 1993.
[11] SCHULZ, M. - Verificação geral de peças de concreto armado baseado no modelo da chapa fissurada, Tese de Doutorado, Universidade Federal do Rio de Janeiro, Rio de Janeiro, 1988.

[12] SCHULZ, M., SANTISI D'AVILA, M. P. - Analysis of Reinforced Concrete Shells with Transverse Shear Forces, ASCE Journal of Structural Engineering, vol. 136, no. 7, 2010, pp. 837-848.

[13] SCHULZ, M., OLIVEIRA, E. - Design procedure for plane elements with skew reinforcement, IABSE Symposium Report, Venice, 2010, pp. 46-53 (8).

[14] EUROCODE 2: Design of concrete structures - Part 1-1: General rules and rules for buildings, CEN, EN 1992-1-1, Brussels, 2004.

[15] ROBINSON, J. R., DEMORIEUX, J. M. - Essais de tractioncompression sur modèles d'âme de poutre en béton armé (Compte rendu partiel II), Institut de Recherches Appliquées du Béton Armé, Paris, 1972.

\section{Table 8}

Reinforcement area and concrete stresses on girder bridges with $k_{c}=0.3$ and $k_{z}=0.9$

\begin{tabular}{|c|c|c|c|c|c|c|c|c|}
\hline \multirow[b]{2}{*}{ Point } & \multicolumn{4}{|c|}{$a_{s \alpha, \text { sup, max }}\left(\mathrm{cm}^{2} / \mathrm{m}\right) / a_{s \alpha, \text { in, }, \text { ax }}\left(\mathrm{cm}^{2} / \mathrm{m}\right)$} & \multicolumn{4}{|c|}{$a_{s \beta, \text { sup, max }}\left(\mathrm{cm}^{2} / \mathrm{m}\right) / a_{s \beta, \text { in, } \text {, ax }}\left(\mathrm{cm}^{2} / \mathrm{m}\right)$} \\
\hline & $\gamma=0^{\circ}$ & $\gamma=15^{\circ}$ & $\gamma=30^{\circ}$ & $\gamma=45^{\circ}$ & $\gamma=0^{\circ}$ & $\gamma=15^{\circ}$ & $\gamma=30^{\circ}$ & $\gamma=45^{\circ}$ \\
\hline 1 & $3.07 / 2.02$ & $3.22 / 1.5$ & $1.58 / 0.86$ & $0 / 8.15$ & $4.47 / 2.52$ & $5 / 1.74$ & $6.07 / 0.55$ & $0 / 0$ \\
\hline 2 & $2.84 / 1.91$ & $5.21 / 3.6$ & $8.82 / 5.32$ & $12.87 / 3.61$ & $2.87 / 3.86$ & $5.32 / 5.46$ & $9.2 / 7.22$ & $13.95 / 5.53$ \\
\hline 3 & $3.07 / 2.02$ & $3.55 / 2.56$ & $3.56 / 3.11$ & $3.56 / 0$ & $4.47 / 2.52$ & $4.04 / 3.6$ & $3.46 / 4.9$ & $10.53 / 0.77$ \\
\hline 4 & $0 / 0$ & $0 / 0$ & $0 / 0$ & $0 / 0$ & $3.12 / 0$ & $1.59 / 0$ & $0 / 0$ & $0 / 0$ \\
\hline 5 & $0 / 0$ & $0 / 0$ & $0 / 0$ & $0 / 0$ & $1.52 / 0.38$ & $0.03 / 0$ & $0 / 0$ & $0 / 0$ \\
\hline 6 & $0 / 0$ & $0 / 0$ & $0 / 0$ & $0 / 0$ & $3.12 / 0$ & $1.59 / 0$ & $0 / 0$ & $0 / 0$ \\
\hline 7 & $0.57 / 0$ & $0.56 / 0$ & $3.27 / 2.25$ & $7.33 / 2.73$ & $2.14 / 0.58$ & $1.77 / 0.71$ & $4.8 / 5.41$ & $13.58 / 6.25$ \\
\hline 8 & $0.4 / 0$ & $1.78 / 0$ & $5.59 / 1.95$ & $7.97 / 5.98$ & $1.94 / 0.98$ & $3.67 / 1.34$ & $8.3 / 4.9$ & $10.77 / 8.2$ \\
\hline 9 & $0.57 / 0$ & $1.77 / 0$ & $4.92 / 1.45$ & $0 / 0$ & $2.14 / 0.58$ & $3.22 / 1.33$ & $6.27 / 4.26$ & $2.97 / 4.13$ \\
\hline 10 & $0 / 0$ & $0 / 0$ & $0 / 0$ & $0 / 0$ & $0 / 3.21$ & $0 / 3.61$ & $0 / 7.09$ & $8.49 / 0$ \\
\hline 11 & $0 / 0$ & $0 / 0$ & $0 / 0$ & $0 / 8.58$ & $0 / 7.57$ & $0 / 8.31$ & $0 / 16.41$ & $0 / 31.19$ \\
\hline 12 & $0 / 0$ & $0 / 0$ & $0 / 0$ & $0 / 0$ & $0 / 3.21$ & $0 / 3.61$ & $0 / 7.09$ & $8.49 / 0$ \\
\hline
\end{tabular}

\begin{tabular}{|c|c|c|c|c|c|c|c|c|}
\hline \multirow[b]{2}{*}{ Point } & \multicolumn{4}{|c|}{$\left|\sigma_{c \phi, \text { sup }}\right|_{\max }(\mathrm{MPa})$} & \multicolumn{4}{|c|}{$\left|\sigma_{c \phi, \text { inf }}\right|_{\max }(\mathrm{MPa})$} \\
\hline & $\gamma=0^{\circ}$ & $\gamma=15^{\circ}$ & $\gamma=30^{\circ}$ & $\gamma=45^{\circ}$ & $\gamma=0^{\circ}$ & $\gamma=15^{\circ}$ & $\gamma=30^{\circ}$ & $\gamma=45^{\circ}$ \\
\hline 1 & -5.94 & -7.29 & -10.5 & -16.98 & -4.46 & -6.01 & -9.65 & -19.36 \\
\hline 2 & -5.32 & -7.05 & -11.04 & -17 & -3.49 & -5.06 & -7.29 & -5.95 \\
\hline 3 & -5.94 & -5.44 & -5.05 & -7.75 & -4.46 & -4.24 & -4.99 & -4.72 \\
\hline 4 & 0 & -24.94 & -26.57 & -23.51 & -19.29 & -19.77 & -21.14 & -29.88 \\
\hline 5 & -15.06 & -22.78 & -24.71 & -28.76 & -7.26 & -17.14 & -18.33 & -20.83 \\
\hline 6 & 0 & -24.94 & -26.57 & -23.51 & -19.29 & -19.77 & -21.14 & -29.88 \\
\hline 7 & -2.51 & -1.97 & -5.97 & -12.28 & -2.7 & -2.42 & -5.05 & -5.98 \\
\hline 8 & -1.98 & -3.83 & -9.53 & -13.64 & -2.35 & -2.5 & -5.87 & -10.69 \\
\hline 9 & -2.51 & -3.97 & -8.31 & -3.51 & -2.7 & -2.96 & -5.3 & -3.31 \\
\hline 10 & -24.11 & -24.03 & -28.17 & -19.99 & -14.58 & -17.54 & -22.01 & -23.26 \\
\hline 11 & -23.18 & -22.72 & -25.56 & -20.97 & -14.45 & -16.54 & -22.42 & -36.56 \\
\hline 12 & -24.11 & -24.03 & -28.17 & -19.99 & -14.58 & -17.54 & -22.01 & -23.26 \\
\hline
\end{tabular}


Skew decks in reinforced concrete bridges

\section{Table 9}

Reinforcement area and concrete stresses on girder bridges with MC 90 parameters

\begin{tabular}{|c|c|c|c|c|c|c|c|c|}
\hline \multirow[b]{2}{*}{ Point } & \multicolumn{4}{|c|}{$a_{s \alpha, \text { sup, max }}\left(\mathrm{cm}^{2} / \mathrm{m}\right) / a_{s \alpha, \text { in, } \text { max }}\left(\mathrm{cm}^{2} / \mathrm{m}\right)$} & \multicolumn{4}{|c|}{$a_{s \beta, \text { sup, max }}\left(\mathrm{cm}^{2} / \mathrm{m}\right) / a_{s \beta, \text { in, }, \text { ax }}\left(\mathrm{cm}^{2} / \mathrm{m}\right)$} \\
\hline & $\gamma=0^{\circ}$ & $\gamma=15^{\circ}$ & $\gamma=30^{\circ}$ & $\gamma=45^{\circ}$ & $\gamma=0^{\circ}$ & $\gamma=15^{\circ}$ & $\gamma=30^{\circ}$ & $\gamma=45^{\circ}$ \\
\hline 1 & $3.36 / 1.73$ & $3.72 / 1.3$ & $2.16 / 0.33$ & $0 / 15.02$ & $4.88 / 2.11$ & $5.72 / 1.28$ & $7.32 / 0$ & $0 / 0$ \\
\hline 2 & $3.16 / 1.59$ & $5.74 / 3.08$ & $9.74 / 4.4$ & $14.69 / 1.78$ & $2.96 / 3.82$ & $5.54 / 5.29$ & $9.71 / 6.77$ & $15.31 / 4.17$ \\
\hline 3 & $3.36 / 1.73$ & $3.85 / 2.26$ & $3.85 / 2.82$ & $6.33 / 0$ & $4.88 / 2.11$ & $4.21 / 3.43$ & $3.38 / 4.97$ & $13.42 / 0.64$ \\
\hline 4 & $0 / 0$ & $0 / 0$ & $0 / 0$ & $0 / 0$ & $3.91 / 0.41$ & $2.44 / 0$ & $0 / 0$ & $0 / 0$ \\
\hline 5 & $0 / 0$ & $0 / 0$ & $0 / 0$ & $0 / 0$ & $1.98 / 0$ & $0.57 / 0$ & $0 / 0$ & $0 / 0$ \\
\hline 6 & $0 / 0$ & $0 / 0$ & $0 / 0$ & $0 / 0$ & $3.91 / 0.41$ & $2.44 / 0$ & $0 / 0$ & $0 / 0$ \\
\hline 7 & $1.19 / 0$ & $1.61 / 0$ & $5.32 / 3.75$ & $6.94 / 2.71$ & $2.59 / 0.96$ & $2.53 / 0.97$ & $6.3 / 6.78$ & $14.87 / 6.66$ \\
\hline 8 & $1.08 / 0$ & $2.92 / 0$ & $8.05 / 3.02$ & $10.72 / 7.34$ & $2.46 / 1.21$ & $4.51 / 2.05$ & $10.11 / 5.95$ & $12.95 / 9.6$ \\
\hline 9 & $1.19 / 0$ & $2.82 / 0$ & $7.11 / 2.25$ & $0 / 0$ & $2.59 / 0.96$ & $3.92 / 2.09$ & $7.76 / 5.08$ & $3.5 / 4.96$ \\
\hline 10 & $0 / 0$ & $0 / 0$ & $0 / 0$ & $0 / 0$ & $0 / 4.11$ & $0 / 4.71$ & $0 / 9.92$ & $10.75 / 0$ \\
\hline 11 & $0 / 0$ & $0 / 0$ & $0 / 0$ & $0 / 18.67$ & $0 / 9.56$ & 0/10.74 & $0 / 23.84$ & $0 / 40.46$ \\
\hline 12 & $0 / 0$ & $0 / 0$ & $0 / 0$ & $0 / 0$ & $0 / 4.11$ & $0 / 4.71$ & $0 / 9.92$ & $10.75 / 0$ \\
\hline
\end{tabular}

\begin{tabular}{|c|c|c|c|c|c|c|c|c|}
\hline \multirow[b]{2}{*}{ Point } & \multicolumn{4}{|c|}{$\left|\sigma_{c \phi, s u p}\right|_{\text {max }}(\mathrm{MPa})$} & \multicolumn{4}{|c|}{$\left|\sigma_{c \phi, \text { inf }}\right|_{\max }(\mathrm{MPa})$} \\
\hline & $\gamma=0^{\circ}$ & $\gamma=15^{\circ}$ & $\gamma=30^{\circ}$ & $\gamma=45^{\circ}$ & $\gamma=0^{\circ}$ & $\gamma=15^{\circ}$ & $\gamma=30^{\circ}$ & $\gamma=45^{\circ}$ \\
\hline 1 & -3.32 & -4.04 & -5.77 & -8.68 & -2.11 & -2.9 & -4.79 & -11.02 \\
\hline 2 & -3.04 & -4.01 & -6.28 & -9.95 & -1.55 & -2.32 & -3.29 & -2.02 \\
\hline 3 & -3.32 & -3.02 & -2.77 & -5.86 & -2.11 & -2.03 & -2.47 & -2.74 \\
\hline 4 & 0 & -13.39 & -14.32 & -11.61 & -9.71 & -9.95 & -10.58 & -16.26 \\
\hline 5 & -8.76 & -12.3 & -13.46 & -15.9 & -3.46 & -8.55 & -9.12 & -10.12 \\
\hline 6 & 0 & -13.39 & -14.32 & -11.61 & -9.71 & -9.95 & -10.58 & -16.26 \\
\hline 7 & -1.63 & -1.56 & -4.21 & -6.51 & -1.53 & -1.47 & -3.63 & -3.13 \\
\hline 8 & -1.41 & -2.62 & -6.37 & -8.78 & -1.44 & -1.59 & -3.79 & -6.49 \\
\hline 9 & -1.63 & -2.59 & -5.5 & -1.93 & -1.53 & -1.65 & -3.31 & -1.82 \\
\hline 10 & -13.04 & -13 & -15.28 & -10.41 & -7.29 & -8.76 & -11.52 & -12.66 \\
\hline 11 & -12.67 & -12.39 & -13.93 & -11.54 & -7.21 & -8.32 & -12.93 & -25.42 \\
\hline 12 & -13.04 & -13 & -15.28 & -10.41 & -7.29 & -8.76 & -11.52 & -12.66 \\
\hline
\end{tabular}
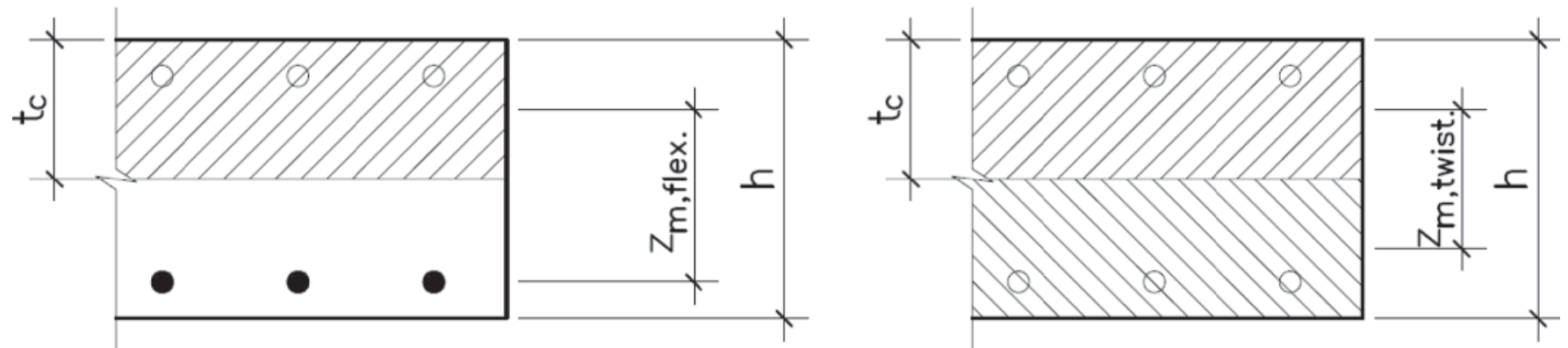

Figure 16

Panel thickness and lever arm considered 


\section{Table 10}

Total steel mass and ratios for girder bridges

\begin{tabular}{|c|c|c|c|c|}
\hline \multirow{2}{*}{$\gamma$} & \multirow{2}{*}{$\begin{array}{c}\text { Total steel } \\
\text { mass (kg) }\end{array}$} & \multicolumn{2}{|c|}{ Ratios } & \multirow{2}{*}{$\mathbf{P} / \mathbf{P}_{0^{\circ}}$} \\
\cline { 3 - 4 } & & $\mathrm{kg} / \mathrm{m}^{2}$ & $\mathrm{~kg} / \mathrm{m}^{3}$ & \\
\hline $0^{\circ}$ & 8985 & 19 & 85 & 1.00 \\
\hline $15^{\circ}$ & 11478 & 25 & 108 & 1.28 \\
\hline $30^{\circ}$ & 21345 & 46 & 201 & 2.38 \\
\hline $45^{\circ}$ & 51592 & 112 & 487 & 5.74 \\
\hline
\end{tabular}

[16] LEONHARDT, F; MÖNNIG, E. - Construções de concreto - vol. 2: Casos Especiais de Dimensionamento de Estruturas de Concreto Armado, tradução: V. L. E. Merino, Editora Interciência, Rio de Janeiro, 1978.

[17] EUROCODE 2: Design of concrete structures - Part 2: Concrete bridges - Design and detailing, CEN, EN 1992-2, Brussels, 2005.

[18] BERTAGNOLI, G., GIORDANO, L., MANCINI, S - Design and optimization of skew reinforcement in concrete shells, Structural Concrete, vol. 13/4, 2012, pp. 248-258.

[19] ABNT - NBR 6118:2014 - Projeto de estruturas de concreto - Procedimento, Associação Brasileira de Normas Técnicas, 2014.

[20] ROCHA, B. F. - Dimensionamento de lajes de pontes com armadura esconsa baseado no modelo da chapa fissurada, Dissertação de Mestrado, Universidade Federal Fluminense, Niterói, Rio de Janeiro, 2015.

[21] MARTI, P. - Design of concrete slabs for transverse shear, ACI Structural Journal, vol. 87(2), 1990, pp. 180-190.

[22] CSI Computers \& Structures - SAP 2000 Basic Analysis Reference Manual, Berkeley, 2009.

[23] ABNT - NBR 7188:2013 - Carga móvel rodoviária e de pedestres em pontes, viadutos, passarelas e outras estruturas, Associação Brasileira de Normas Técnicas, 2013.

[24] ABNT - NBR 8681:2003 - Ações e segurança nas estruturas - Procedimento, Associação Brasileira de Normas Técnicas, 2003. 